http://dx.doi.org/10.15361/1984-5529.2015v43n2p149-155

\title{
Development of cv. BRS Novaera cowpea inoculated with rhizobium recommended for pigeonpea
}

\section{Desenvolvimento do feijão caupi cv. BRS Novaera inoculado com rizóbio recomendado para feijão guandu}

\author{
Salomão Lima GUIMARÃES ${ }^{1}$; Milly Siqueira CARDINAL ${ }^{2}$; Edna Maria Bonfim-SILVA ${ }^{3}$; \\ Analy Castilho POLIZEL ${ }^{4}$ \\ ${ }^{1}$ Autor para correspondência. Professor Adjunto. Universidade Federal de Mato Grosso, Campus Rondonópolis. \\ Rodovia MT 270, Km 06, CEP.78735-91, Sagrada Família, Rondonópolis - MT. Email.: slguimaraes@ufmt.br \\ ${ }^{2}$ Estudante de graduação em Engenharia Agrícola e Ambiental. Universidade Federal de Mato Grosso, Campus \\ Rondonópolis. Email.: millycardinal@hotmail.com \\ ${ }^{3}$ Professor Adjunto. Universidade Federal de Mato Grosso, Campus Rondonópolis. Email.: embonfim@hotmail.com \\ ${ }^{4}$ Professor Adjunto. Universidade Federal de Mato Grosso, Campus Rondonópolis. Email.: analy@ufmt.br
}

Recebido em: 11-04-2014; Aceito em: 15-11-2014

\begin{abstract}
The cultivation of cowpea (Vigna unguiculata) has grown in Brazil, especially in the Cerrado of Mato Grosso, where it is produced in off-season. The association of cowpea plants with rhizobia has provided much of the nitrogen required by this culture. This study aimed at evaluating the development of cowpea inoculated with rhizobia recommended for pigeonpea (Cajanus cajan). The experiment was conducted at the Federal University of Mato Grosso, University Campus Rondonópolis-MT under greenhouse conditions. The experimental design was completely randomized with three treatments and four replications. The treatments were composed by commercial inoculant recommended for pigeonpea (composed by the combination of strains BR2003 and BR2801), nitrogen (without inoculation and application of $50 \mathrm{mg} \mathrm{N} \mathrm{dm}^{-3}$ ) and a control (without inoculation and nitrogen fertilization). Plants height, SPAD index, number of pods, number of grain, number of nodules, length of pods, dry weight of nodules, dry grain, dry weight of shoot and relative efficiency of the strains were analyzed. Cowpea show significant response for inoculation in all variables, with increase in production equal or superior to the treatment with nitrogen fertilizer. These results indicate the inoculant recommended for pigeonpea has potential use for cowpea under the tested conditions.
\end{abstract}

Additional keywords: cerrado; inoculation; Vigna unguiculata.

\section{Resumo}

O cultivo do feijão caupi (Vigna unguiculata) tem crescido no Brasil, especialmente no cerrado matogrossense, onde vem sendo produzido na safrinha. A associação de plantas de feijão caupi com o rizóbio tem suprido grande parte do nitrogênio requerido por essa cultura. Assim, objetivou-se, com esse trabalho, avaliar o desenvolvimento do feijão caupi inoculado com rizóbio recomendado para o feijão guandu (Cajanus cajan). O experimento foi conduzido na Universidade Federal do Mato Grosso, Campus Universitário de Rondonópolis-MT, em casa de vegetação. O delineamento experimental utilizado foi inteiramente casualizado, com três tratamentos e quatro repetições. Os tratamentos foram compostos por um inoculante comercial recomendado para o feijão guandu (composto pela combinação das estirpes BR2003 e BR2801), adubação nitrogenada (sem inoculação e com aplicação de $50 \mathrm{mg} \mathrm{N} \mathrm{dm}^{-3}$ ) e um controle (sem inoculação e sem adubação nitrogenada). As variáveis analisadas foram altura das plantas, índice SPAD, número de vagens, número de grãos, número de nódulos, comprimento de vagens, massa seca de nódulos, massa seca de grãos, massa seca da parte aérea e a eficiência relativa das estirpes. O feijão caupi respondeu significativamente à inoculação em todas as variáveis analisadas, com incrementos na produção iguais ou superiores à adubação nitrogenada. Esses resultados indicam que nas condições testadas, o inoculante recomendado para o feijão guandu apresenta potencial de uso para o feijão caupi.

Palavras-chave adicionais: cerrado; inoculação; Vigna unguiculata.

\section{Introduction}

In Brazil, cowpea (Vigna unguiculata) production is concentrated mainly in the Northeastern and Northern regions. However, it is gaining space in the Midwestern region due to the development of cultivars with characteristics that favor its cultivation, being incorporated into productive arrangements as second crop, thus increasing the interest of producers for this culture (Freire Filho et al., 2011).

Given this scenario, it is extremely important to study new technologies that intend to increase production sustainably and without increasing costs. In this context, legumes such as cowpea have a key role 
in agriculture, since they have the capacity of association with nitrogen-fixing bacteria such as rhizobium, getting much of the nitrogen required for their development (Zilli et al., 2009, Guimarães et al ., 2013).

The use of nitrogen fertilizers in tropical soils, besides their high cost of production, also have an additional ecological cost, considering that the loss of applied nitrogen fertilizers are of around $50 \%$, what is mainly caused by leaching and runoff caused by rainfall and/or irrigation (Straliotto et al., 1999).

Biological nitrogen fixation (BNF) has been proved essential for the sustainability of Brazilian agriculture, given the fact that it supplies nitrogen to crops with low economic cost and reduced environmental impact, improving its agronomic efficiency (Hungria \& Bohrer, 2000; Lima et al., 2011; Florentino \& Moreira, 2009).

Techniques such as cowpea seeds inoculation with rhizobium prospect the generation of high agronomic efficiency in this culture. In addition, the use of rhizobium inoculants in grain legumes has been responsible for significant savings in the cost of agricultural production, by reducing the use of nitrogen mineral fertilizers as a benefit of the BNF process (Xavier et al., 2008).

In the state of Mato Grosso, studies conducted with inoculation techniques in cowpea through the use of rhizobium lineages are still limited or nonexistent. This study aimed to evaluate the development of cowpea inoculated with rhizobium recommended for pigeonpea and grown in Cerrado Oxisol.

\section{Material and methods}

The inoculation experiment in cowpea (Vigna unguiculata) with rhizobium inoculant recommended for pigeonpea (Cajanus cajan) was conducted in a greenhouse at the Federal University of Mato Grosso, Rondonópolis Campus, municipality geographically located in the southern region of the state, at latitude 16-28'15 South and longitude 5438'08 West.

The experimental design was a completely randomized with a cultivar of cowpea (BRS Novaera), three treatments and four replications. The treatments consisted of a commercial inoculant recommended for pigeonpea (formed by the combination of BR2003 and BR2801 lineages), nitrogen (without inoculation and with the application of $50 \mathrm{mg} \mathrm{N} \mathrm{dm}^{-3}$ ) and a control (without inoculation and nitrogen fertilization).

Fertilization was performed with phosphorus $\left(\mathrm{P}_{2} \mathrm{O}_{5}\right)$ and potassium $\left(\mathrm{K}_{2} \mathrm{O}\right)$, with 400 and $100 \mathrm{mg}$ $\mathrm{dm}^{-3}$, respectively, using superphosphate and potassium chloride as sources.

The inoculation was performed by pelleting the seeds in the proportion of $500 \mathrm{~g}$ of inoculant per each $50 \mathrm{~kg}$ of seeds (Guimarães et al., 2007). Subsequently, the seeds were put to dry in the shade and then sown in pots.

Planting was done by sowing in pots with
$8 \mathrm{dm}^{3}$ of soil capacity, in which five seeds were sown per vase, leaving three plants after thinning.

The evaluations were made in the $R 1$ (beginning of flowering) and R3 (beginning of the pods maturation) growth stages, considering the following variables: plant height, SPAD index, number of nodules, nodule dry matter, number of pods, pods length, number of grains, grains dry matter, total dry matter and the relative efficiency of the lineages, using dry biomass shoot part parameter (Bergensen et al., 1971).

Data were subjected to analysis of variance by $\mathrm{F}$ test, and means were compared by Tukey test at $5 \%$ significance level, using the SISVAR 4.2 statistical program (Ferreira, 2008).

\section{Results and discussions}

The inoculation of cowpea seeds with rhizobium inoculant recommended for pigeonpea provided increments for the analyzed variables, with similar effects to the treatment in which plants received nitrogen fertilizer, besides setting higher development to plants that made up the control treatment.

The best performance for plant height in the R1 stage was observed in the nitrogen treatment, followed by the treatment in which plants were inoculated with the commercial inoculant. However, the results observed in the treatment with inoculation were not different from those of the control treatment. In the R3 stage, the inoculated plants showed similar development to those that received nitrogen fertilization, showing also higher height when compared to the control (Figure 1A).

These results differ from those found by Figueiredo et al. (2008), who found higher plant height in inoculated treatments. Guareschi et al. (2011) found that with the application of inoculant with Bradyrhizobium japonicum in adzuki beans, there was a higher plant height compared to the other treatments, except for the treatment without inoculation. This result is similar to that found in this work only by the evaluation in the R3 stage, where the control treatment showed lower height when compared to the other treatments.

Machado et al. (2008), while studying cowpea genotypes for earliness, plant architecture and grain yield, found that the average height of plants ranged from $37.2 \mathrm{~cm}$ to $41.33 \mathrm{~cm}$. The results found by these authors differ from those found in this study, where plants height, except for the absolute control, ranged from $42.5 \mathrm{~cm}$ to $44.25 \mathrm{~cm}$ in the R3 stage.

The SPAD index provide readings that are correlated with the chlorophyll content in leaves, making it a more practical tool for the evaluation of nitrogen content in leaves, since the leaf chlorophyll concentration is positively correlated with the nitrogen content in plants and with the crop yield (Schadchina \& Dmitrieva, 1995). 

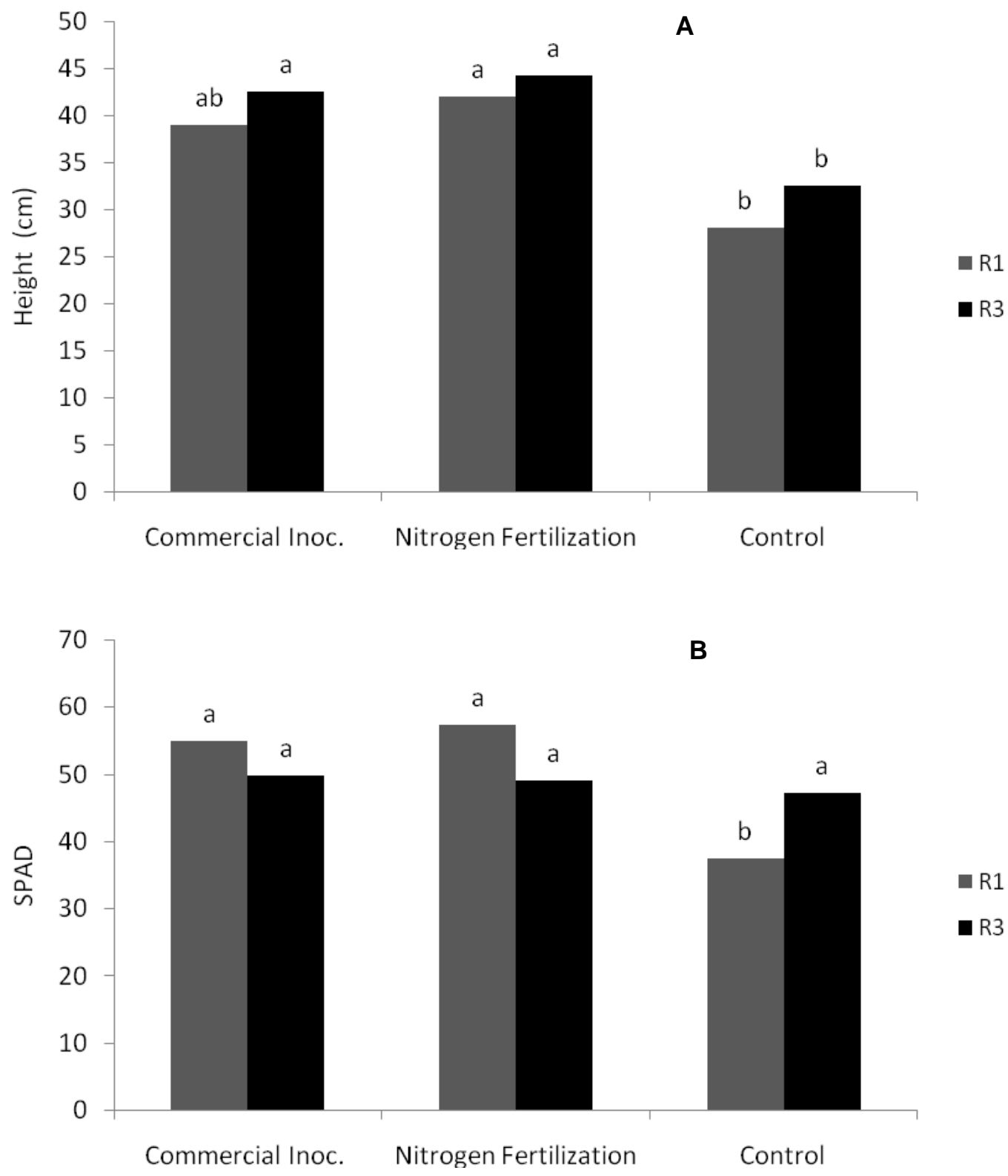

Figure 1 - Height $(A)$ and SPAD index (B) of cowpea bean plants (Vigna unguiculata) inoculated with rhizobium lineages recommended for pigeonpea (Cajanus cajan). Means followed by the same letter do not differ by Tukey test at $5 \%$ significance level.

The results obtained for the SPAD index were significant in the first reading, held at the beginning of flowering, corresponding to the R1 stage (Figure 1B). The plants that received nitrogen fertilization showed higher cumulative chlorophyll content in leaves (57.40), followed by the commercial inoculant (55.00) and the control (37.4).

In the second reading, held at the beginning of the pods maturation, R3 stage, the SPAD index was not significant because many leaves had already lost its original chlorophyll content or had even suffered abscission (Figure 1B). The results observed in the R1 stage corroborate with Vieira et al. (2010), who reported that the treatments fertilized with nitrogen gave the largest increments of nitrogen in plants.
At the pod maturation phase (R3 stage), no differences were found in the chlorophyll content between treatments, which can be related to the decrease in nitrogen concentration in the vegetative fraction of the plant, translocating it to the grains. Experiments conducted by Almeida et al. (2010) with rhizobium inoculation on cowpea in the state of Piauí showed no significant difference between inoculated treatments and the control (without inoculation and without fertilization) to the nitrogen content in plants, corroborating with the results obtained in this study.

The difference between the number of cowpea pods present in the treatments was significant, and the occurrence of pods was considerably lower in the control treatment comparing to the other 
treatments (Figure 2A). The average number of pods value found in this study, obtained in the inoculated plants, was of 9.5 , which is below the results obtained by Santos et al. (2009), who found 10.05 as the average number of pods.

Pods length was significant in all treatments, where it was observed that the commercial inoculant (average value of $12.74 \mathrm{~cm}$ ) was statistically equal

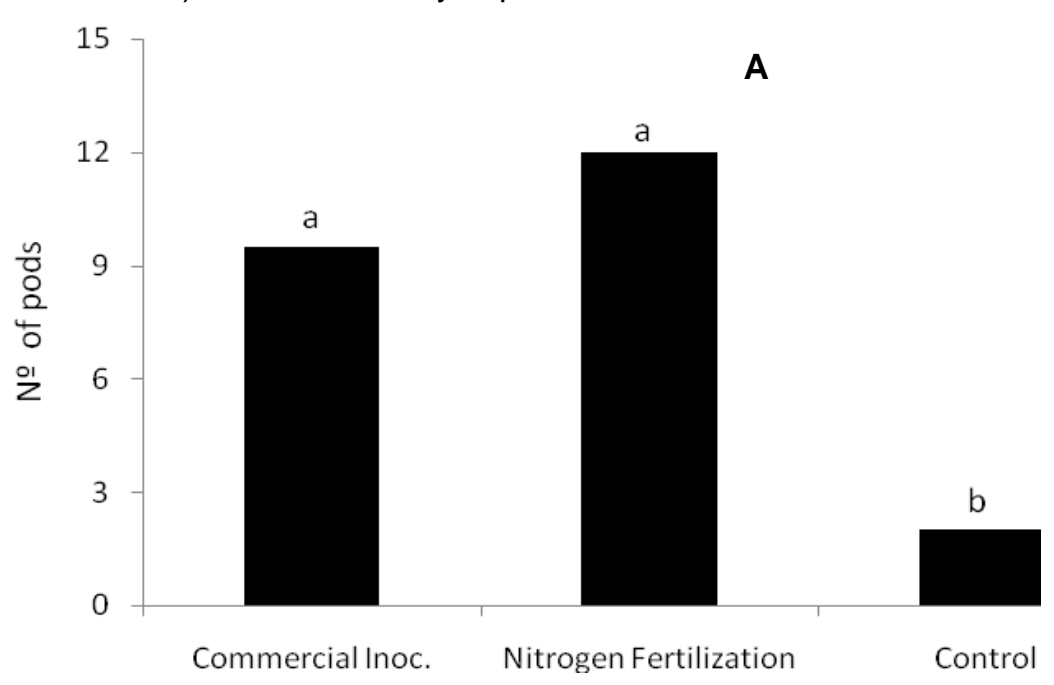

B

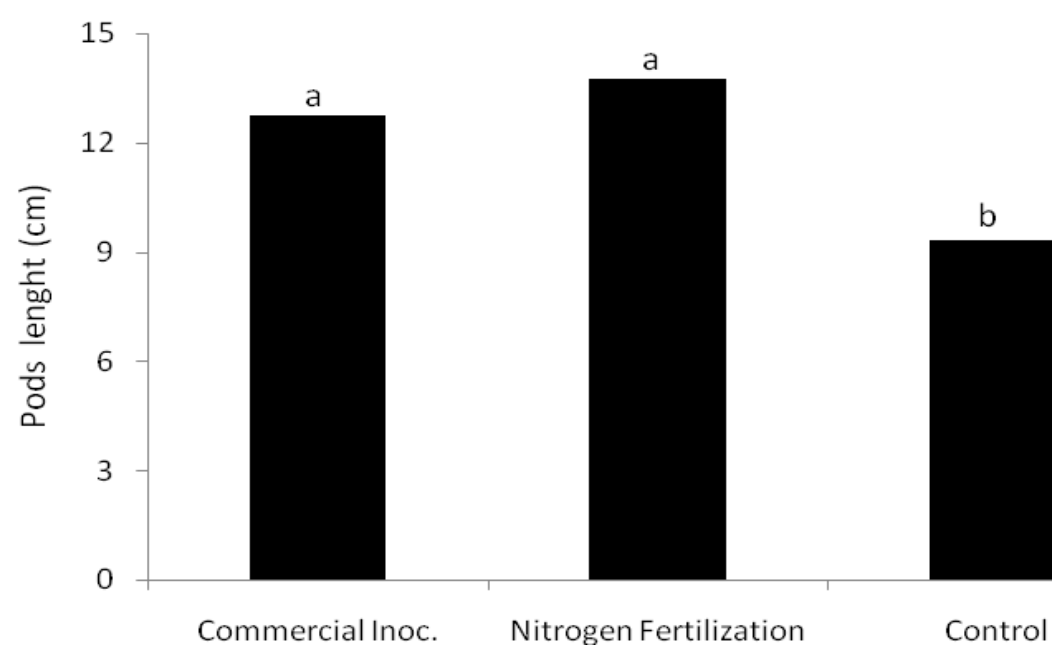

Figure 2 - Number $(A)$ and length of pods (B) of cowpea (Vigna unguiculata) inoculated with rhizobium lineages recommended for pigeonpea (Cajanus cajan). Means followed by the same letter do not differ by Tukey test at $5 \%$ significance level.

Although it is generally agreed that pods length is related to productivity, this condition is not always the most desirable, since in production systems in which the use of semi-mechanized and mechanized harvesting is advocated, pods of smaller sizes are more suitable to this type of management for being less conducive to touch the ground, thus preventing decay (Silva \& Neves, 2011).

According Gerlach et al. (2013), there is a tendency to increase beans yield along with the to that of the treatment that received nitrogen fertilization $(13.7 \mathrm{~cm})$. Only the control showed lower pods length $(9.3 \mathrm{~cm})$, showing similar behavior to the number of pods (Figure 2B). These results disagree with those found by Guedes et al. (2010), of pods length ranging from $15 \mathrm{~cm}$ to $18.94 \mathrm{~cm}$. which under similar conditions had average values 

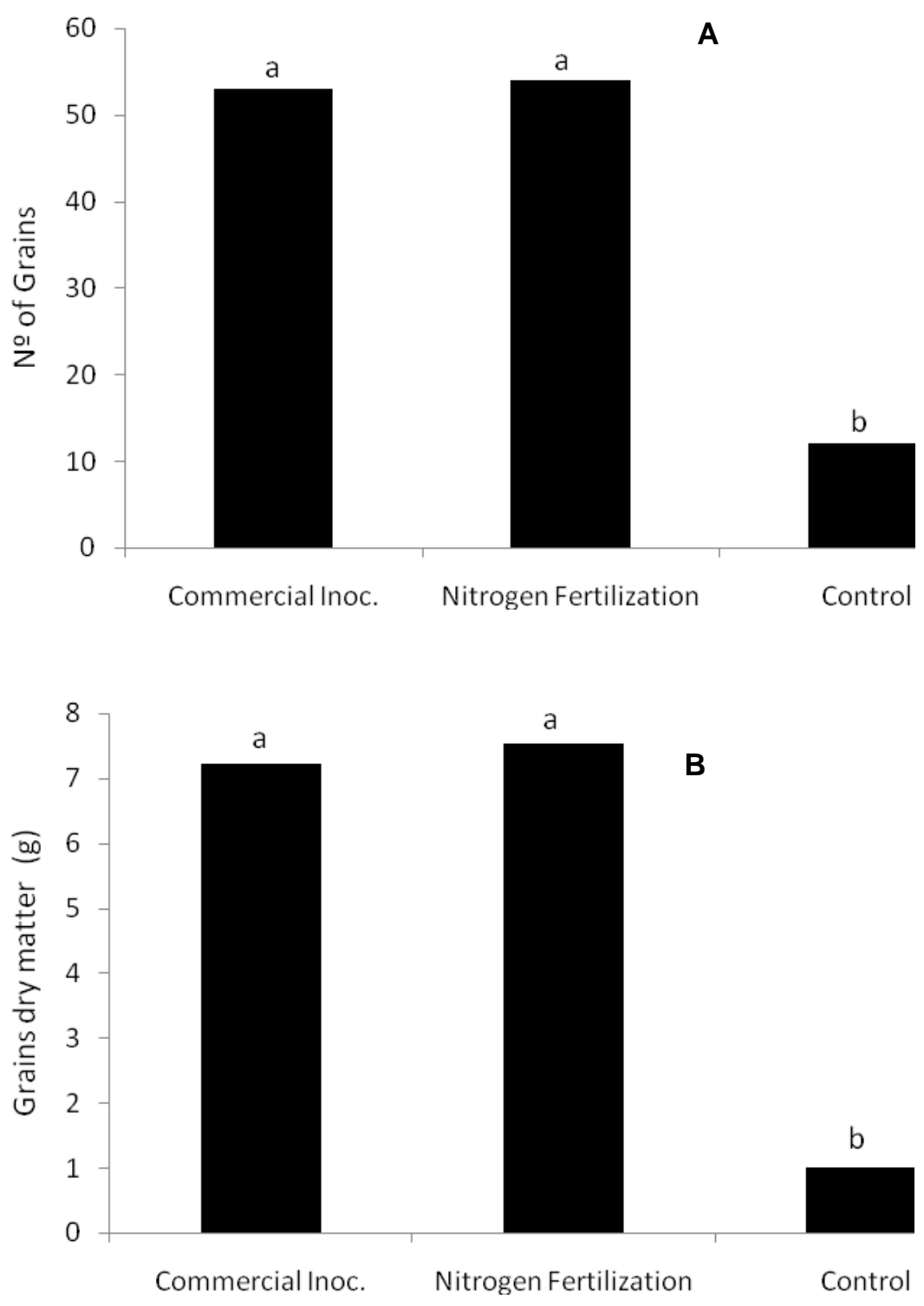

Figure 3 - Number (A) and dry matter (B) of cowpea grains (Vigna unguiculata) inoculated with rhizobium strains recommended for pigeonpea (Cajanus cajan). Means followed by the same letter do not differ by Tukey test at $5 \%$ significance level.

These results are opposite to those found by Borges et al. (2012), who obtained the highest grain average to a vinegar cultivar in the control treatment, and corroborate with the experiment conducted by Chagas et al. (2010), who observed a positive response regarding this variable inoculation.

Xavier et al. (2008), while evaluating inoculation and nitrogen fertilization on nodulation and cowpea grain yield, concluded that productivity increases with the use of inoculation and the effect of this practice is favored when the cowpea is fertilized with a maximum of $20 \mathrm{~kg} \mathrm{ha}^{-1}$ of nitrogen.

In the study conducted by Guedes et al. (2010), evaluating the efficiency of inoculants in cowpea in the municipality of Pombal - PB, the authors found no difference between the treatment means for the number of grains per pod variable, occurring in function to the variation between treatments for pods length. Also according to the authors, if the pods had similar length, it is common to retain this similarity as for the number of grains per pod.

In this work, no significant differences were observed for the number of nodules. However, the commercial inoculant excelled the other treatments. Moreover, in relation to the nodules dry matter, a difference was observed between treatments, with higher accumulation observed in plants treated with the commercial inoculant (Table 1).

The establishment and survival capacity of lineages when inoculated in plants which are associated can determine the efficiency in nodulation. Thus, there is still no conclusive information on the minimum number of nodules required to ensure a 
good performance of BNF for the cowpea, which already exists for the soybean crop, in which it $15-20$ nodules in the crown of the main root is recognized as sufficient (Hungria \& Bohrer, 2000).

Table 1 - Number of nodules (NN), dry matter of nodules (DMN), dry matter of shoots (DMS) and relative efficiency $(\mathrm{RF})$ in cowpea plants inoculated with the rhizobium recommended for pigeon pea.

\begin{tabular}{lcccc}
\hline Treatments & $\mathrm{NN}$ & $\mathrm{DMN}\left(\mathrm{g} \mathrm{vase}^{-1}\right)$ & $\mathrm{DMS}\left(\mathrm{g} \mathrm{vase}^{-1}\right)$ & $\mathrm{RF}(\%)$ \\
\hline Commercial inoculant & $14.70 \mathrm{a}^{*}$ & $0.21 \mathrm{a}^{*}$ & $22.60 \mathrm{a}$ & $99.00 \mathrm{a}$ \\
Nitrogen Fertilization & $11.10 \mathrm{a}$ & $0.10 \mathrm{ab}$ & $22.80 \mathrm{a}$ & $100.00 \mathrm{a}$ \\
Control & $9.80 \mathrm{a}$ & $0.02 \mathrm{~b}$ & $8.30 \mathrm{~b}$ & $36.40 \mathrm{~b}$ \\
\hline CV $(\%)$ & 22.51 & 3.26 & 17.13 & 14.11
\end{tabular}

Means followed by the same letter do not differ by Tukey test at 0.05 probability. ${ }^{*}$ Transformed values by square root of $(\mathrm{Y}+1.0)$

Another important observation in this study is related to nodulation in plants that received nitrogen fertilization and to the control, both of which have similar nodules to those of inoculated plants. But in terms of agronomic efficiency, in the variables analyzed above, the commercial inoculant proved to be superior, indicating competition and establishment in the soil capacity (Guimarães et al., 2013).

For the shoot part dry matter variable a difference of the treatments compared to the control was observed, with an increase of more than $100 \%$ (Table 1).

It was noted a great loss of leaf matter at the end of the culture cycle, which was due to leaf senescence and translocation of photo-assimilated to stems and grains (Borges et al., 2012). This behavior occurs because the cowpea can respond to various environmental stimuli, changing its dry matter partitioning throughout the cycle, as a physiologic response to guarantee grain yield (Praxedes et al., 2009, Silva et al., 2009).

In plants inoculated with nitrogen-fixing bacteria, high plants dry matter values have been related to higher nitrogen fixation capacity by more efficient rhizobia (Lima et al., 2011; Florentino \& Moreira, 2009), as well as indicative of high crop yields (Zilli et al., 2009; Ferreira et al., 2009).

The relative efficiency of the lineages is a parameter that serves as an indicator of the nitrogen that is fixed and used by the culture. In the present study, it was observed that the commercial inoculant for pigeon pea, when applied in cowpea cultivation, have a relative efficiency of $99 \%$, clashing the control treatment, with efficiency of only $36 \%$ (Table 1 ).

The rhizobium potential of fixing nitrogen is of fundamental importance for high biomass production, which can be related to the effective capacity in the supply of nitrogen by the tested lineages, which can be demonstrated by the positive correlation between the relative efficiency and the shoot dry mass production (Chagas Júnior et al., 2010).

Similarly, it was demonstrated that the relative efficiency can be high in plants which were not inoculated with nitrogen-fixing bacteria nor fertilized with nitrogen fertilizers. This effect may be related to the cowpea ability to nodule with different rhizobia groups, thus proving the capacity of the native population to establish symbiosis with cowpea (Lima et al., 2011).

In general, the results of the treatments whose plants were inoculated with rhizobium lineages proved to be superior to the control and similar to the treatment that received nitrogen fertilization recommended for this culture, corroborating with Guedes et al. (2010), who also found differences in the inoculated treatments when compared to the absolute control. Other studies have showed the positive effect of the use of rhizobium lineages on the productivity of cowpea (Lacerda et al., 2004, Lima et al., 2005, Soares et al., 2006, Zilli et al., 2009, Zilli et al., 2011).

Further studies on the cowpea-rhizobium interaction should be performed, particularly with experiments in the Mato Grosso Cerrado region under field conditions, so that it can be established, in addition to the inoculant used in this work, which autochthonous lineages have potential for inoculants targeted to the cowpea grown in Mato Grosso.

\section{Conclusions}

Seeds inoculation of cowpea with rhizobium inoculant recommended for pigeonpea resulted in yield of grains equivalent to the plants fertilized with mineral nitrogen.

The rhizobium inoculant recommended for pigeonpea has the potential to be used in cowpea.

\section{References}

Almeida ALG, Alcântara RCM, Nóbrega RSA, Nóbrega JCA, Leite LFC, Silva, JA L (2010) Produtividade do feijão caupi cv BR 17 Gurguéia inoculado com bactérias diazotróficas simbióticas no Piauí. Revista Brasileira de Ciências Agrárias 5(3): 364-369.

Bergensen, FJ, Brockwell J, Gibson $\mathrm{AH}$, Schwinghamer E A (1971) Studies of natural populations and mutants in the improvement of legume inoculants. Plant and Soil 46(1): 3-16.

Borges PRS, Saboya RCC, Saboya LMF, Santos ER, Souza SEA (2012) Distribuição de Massa Seca e Rendimento de Feijão caupi Inoculadas com Rizóbio em Gurupi, TO. Revista Caatinga 25(1): 37-44. 
Chagas Júnior AF, Oliveira LA, Oliveira NA (2010) Eficiência agronômica de estirpes de rizobio inoculadas em feijão caupi no Cerrado, Gurupi-TO. Revista Ciência Agronômica 41(4): 709-714.

Ferreira DF (2008) SISVAR: um programa para análises e ensino de estatística. Revista Symposium 6(1): 6-41.

Ferreira PAA, Silva MAP, Cassetari A, Rufini M, Moreira MFS, Andrade MJB (2009) Inoculação com cepas de rizóbio na cultura do feijoeiro. Ciência Rural 39(7): 2210-2212.

Figueiredo MVB, Martinez CR, Burity HA, Chanway CP (2008) Plant growth promoting rhizobacteria for improving nodulation and nitrogen fixation in the common bean (Phaseolus vulgaris L.). World Journal Microbiology Biotechnology 24(1): 1187-1193.

Florentino LA, Moreira FMS (2009) Características simbióticas e fenotípicas de Azorhizobium doebereinerae, microissimbiote de Sesbania virgata. Revista Árvore 33(2): 215-226.

Freire Filho FR, Ribeiro VQ, Rocha MM, Silva KJD, Nogueira MSR, Rodrigues E V (2011) Feijão caupi no Brasil: Produção, melhoramento genético, avanços e desafios. Embrapa Meio-Norte.84p.

Guareschi RF, Perin A, Gazolla PR, Rocha AC (2011) Nodulação e crescimento vegetativo de feijão azuki (Vigna angularis) submetido à inoculação e adubação nitrogenada. Global Science and Technology 4(3): 75-82.

Guedes GN, Souza AS, Alves LS (2010) Eficiência Agronômica de Inoculantes em Feijão caupi no Município de Pombal-PB. Revista Verde 5(4): 82-89.

Gerlach GAX, Arf O, Corsini DC, Silva JC, Coletti, AJ (2013) Análise econômica da produção de feijão em função de doses de nitrogênio e coberturas vegetais. Pesquisa Agropecuária Tropical 43(1): 42-49.

Guimarães, SL, Baldani, JI, Baldani, VLD, JacobNeto, J (2007) Adição de molibdênio ao inoculante turfoso com bactérias diazotróficas usado em duas cultivares de arroz irrigado. Pesquisa Agropecuária Brasileira. 42(3): 393-398.

Guimarães SL, Baldani VLD, Jacob-Neto J (2013) Viabilidade do inoculante turfoso produzido com bactérias associativas e molibdênio. Revista Ciência Agronômica 44(1): 10-15.

Hungria M, Bohrer TRJ (2000) Variability of nodulation and dinitrogen fixation capacity among soybean cultivars. Biology and Fertility of Soils 31(1): 45-52.

Lacerda AM, Moreira FMS, Andrade MJB, Soares ALL (2004) Efeito de estirpes de rizóbio sobre a nodulação e produtividade do feijão caupi. Ceres 51(293): 67-82.
Lima AST, Barreto MCS, Araújo JM, Seldin L, Burity HA, Figueiredo MVB (2011) Sinergismo Bacillus, Brevibacillus e, ou, Paenibacillus na simbiose Bradyrhizobium-caupi. Revista Brasileira de Ciência do Solo 35(3): 713-721.

Machado CF, Teixeira NJ, Freire Filho FR, Rocha MR, Gomes RLF (2008) Identificação de genótipos de feijão caupi quanto à precocidade, arquitetura da planta e produtividade de grãos. Revista Ciência Agronômica 39(1): 114-123.

Praxedes SC, Ferreira TM, Gomes Filho E (2009) Acúmulo de prolina e aminoácidos em cultivares de feijão caupi com tolerância diferencial à salinidade. Revista Caatinga 22(3): 211-214.

Santos JF, Granjeiro JIT, Brito CH, Santos MCC (2009) A Produção e Componentes Produtivos de Variedades de Feijão Caupi na Microregião do Cariri Paraibano. Engenharia Ambiental 6(1) 214-222.

Schadchina TM, Dmitrieva VV (1995) Leaf chlorophyll content as a possible diagnostic mean for the evaluation of plant nitrogen uptake from the soil. Journal of Plant Nutrition 18(1): 1427-1437.

Silva ALJ, Neves J (2011) Produção de feijão caupi semi-prostrado em cultivos de sequeiro e irrigado. Revista Brasileira de Ciências Agrárias 6(1): 29-36.

Silva,MF, Oliveira, PJ, Xavier, GR, Rumjanek, NG, Reis, VM (2009) Inoculantes formulados com polímeros e bactérias endofíticas para a cultura da cana-de-açúcar. Pesquisa Agropecuária Brasileira, 44(11): 437-1443.

Straliotto R, Cunha CO, Mercante FM, Franco AA, Rumjanek NG (1999) Diversity of rhizobia nodulating common beans (Phaseolus vulgaris L.) isolated from brazilian tropical soils. Anais da Academia Brasileira de Ciências 71(3): 531-543.

Vieira CL, Freitas AD, Silva AF, Sampaio EV, Araújo MS (2010) Inoculação de variedades locais de feijão macassar com estirpes selecionadas de rizóbio. Revista brasileira engenharia agrícola ambiental 14(11): 1170-1175

Xavier TF, Araújo ASF, Santos VB, Campos FL (2008) Inoculação e adubação nitrogenada sobre a nodulação e a produtividade de grãos de feijão caupi. Ciência Rural 38(7): 2037-2041.

Zilli JE, Marson LC, Marson BF, Rumjanek NG, Xavier GR (2009) Contribuição de estirpes de rizóbio para o desenvolvimento e produtividade de grãos de feijão caupi em Roraima. Acta Amazônica 39(4): 749-758.

Zilli JE, Neto MLS, Júnior IF, Perin L, Melo, AR (2011) Resposta do feijão caupi à inoculação com estirpes de Bradyrhizobium recomendadas para a soja. Revista Brasileira de Ciência do Solo 35(1): 739-742. 